\title{
Pemetaan riset terkait tayangan sinetron televisi di Indonesia dalam perspektif akademik
}

\author{
Puji Lestari ${ }^{1}$, Hanny Hafiar ${ }^{2}$, Kholidil Amin ${ }^{3}$ \\ ${ }^{1}$ Universitas Pembangunan Nasional Veteran Yogyakarta, Yogyakarta, Indonesia \\ ${ }^{2,3}$ Universitas Padjadjaran, Bandung, Indonesia
}

\begin{abstract}
ABSTRAK
Tayangan drama atau sinetron populer di televisi dengan rating tinggi telah menarik perhatian sejumlah peneliti untuk mengkajinya dari berbagai aspek. Terdapat beberapa judul sinetron popular di Indonesia yang telah dikaji dalam berbagai bentuk penelitian. Tingginya jumlah kajian, menunjukkan semakin tingginya kesadaran peneliti untuk mengkaji realitas yang aktual, namun sekaligus menimbulkan kekhawatiran terjadinya pengulangan tema riset. Penelitian ini bertujuan untuk melakukan pemetaan hasil penelitian terkait sinetron popular di Indonesia. Metode yang digunakan adalah Bibliometrik. Hasil riset yang berlandaskan berpikir reflektif menunjukkan bahwa sinetron "Anak Jalanan" menjadi sinetron yang paling banyak diteliti. Tingginya jumlah riset tentang judul sinetron ini berkaitan dengan rating and share sinetron tersebut. Tren penelitian terkait sinetron populer juga cenderung meningkat setelah tahun kedua atau ketiga penayangan, dan trennya menurun setelahnya. Penelitian ini juga menemukan bahwa berakhirnya sinetron tidak langsung menghentikan keberlangsungan riset tentang sinetron tersebut. Temuan lainnya adalah terdapat enam klaster topik. Masing-masing klaster yang tercermin dalam kata kunci memiliki karakteristik khusus terkait topik riset-riset terdahulu tentang tayangan sinetron di Indonesia. Adapun implikasi dari temuan ini adalah adanya peningkatan jumlah kajian yang berkaitan dengan masa tayang dikhawatirkan mengarah kepada tren yang bersifat temporer. Terdapatnya similiaritas topik yang tercermin pada kata kunci menunjukkan adanya kesamaan minat, ide, dan penggunaan metode yang harus diantisipasi agar tidak terjadi pengurangan nilai originalitas dan aksiologi dari sebuah karya ilmiah.
\end{abstract}

Kata-kata Kunci: Tayangan televisi; sinetron popular; pemetaan riset; tren riset; bibliometrik

\section{Mapping research related to television soap operas in Indonesia from an academic perspective}

\begin{abstract}
Popular television dramas or soap operas with high ratings have attracted the attention from a number of researchers to examine them from various aspects. There are several popular soap opera titles in Indonesia that have been studied in various forms of research. The high number of studies shows the increasing awareness of researchers to examine the actual reality, but at the same time raises concerns about the repetition of research themes. This study aims to map the research results related to popular soap operas in Indonesia. The method used is Bibliometrics. The research results show that the soap opera "Anak Jalanan" is the most researched soap opera. The high amount of research on this soap opera is related to the rating and share of the soap opera itself. Research trends related to popular soap operas also tend to increase after the second or third year of broadcast, and the trend decreases after that. This study also found that, the end of the soap opera did not immediately stop the continuation of research on the soap opera. Another finding is that there are six topic clusters. Each cluster reflected in the keywords has special characteristics related to the topic of previous research on soap operas in Indonesia. The implication of this finding is that, the increase in the number of studies related to the broadcast period leads to a temporary trend. The similarity of topics reflected in the keywords shows the similarity of interests, ideas, and the use of methods that must be anticipated so there is no reduction in the value of originality and axiology of a scientific work.
\end{abstract}

Keywords: Television shows; popular soap operas; research mapping; research trends; bibliometrics

Korespondensi: Dr. Puji Lestari, S.IP., M.Si. Universitas Pembangunan Nasional Veteran Yogyakarta. Jl. Babarsari No.2, Caturtunggal, Kecamatan Depok, Kabupaten Sleman, Daerah Istimewa Yogyakarta 55281.Email: puji.lestari@upnyk.ac.id 


\section{PENDAHULUAN}

Media merupakan bagian penting dalam kehidupan masyarakat modern saat ini. Media menjadi sumber informasi, pendidikan dan hiburan. Media menjadi alat komunikasi sosial dan isi media adalah cerminan manusia dan kehidupannya. Melalui media dan isinya, individu dapat mengetahui dan membayangkan kehidupan orang lain yang mungkin saja sama atau berbeda dengan yang dialaminya. Di Indonesia, televisi merupakan media mainstream yang memiliki jumlah konsumen terbesar, walaupun keberadaan media internet telah mengambil sebagian komunikan televisi. Hanya saja di kalangan milenial, televisi masih menjadi media nomor satu yang dikonsumsi oleh publik. Hal ini merujuk pada data yang ditampilkan pada Gambar 1.
Beberapa jenis tayangan televisi yang diminati penonton di Indonesia di antaranya adalah sinetron, infotainment, reality show, dan berita. Besarnya minat masyarakat Indonesia terhadap sinetron, tidak jarang sebuah sinetron ditayangkan secara stripping hingga beratus-ratus episode. Hal ini menyebabkan sejumlah stasiun televisi dan rumah produksi berlomba untuk menghasilkan sinetron yang dapat dipasang pada prime time guna menarik pengiklan. Pengiklan juga lebih tertarik apabila rating dan share acara televisi tersebut tinggi (Nandaryani et al., 2019). Rating dan share menjadi tolak ukur dalam acara televisi (Rahayu et al., 2019). Rating merupakan ukuran tingkat popularitas program televisi terhadap penonton (Indrajati et al., 2020), sedangkan share merupakan persentase jumlah penonton dalam

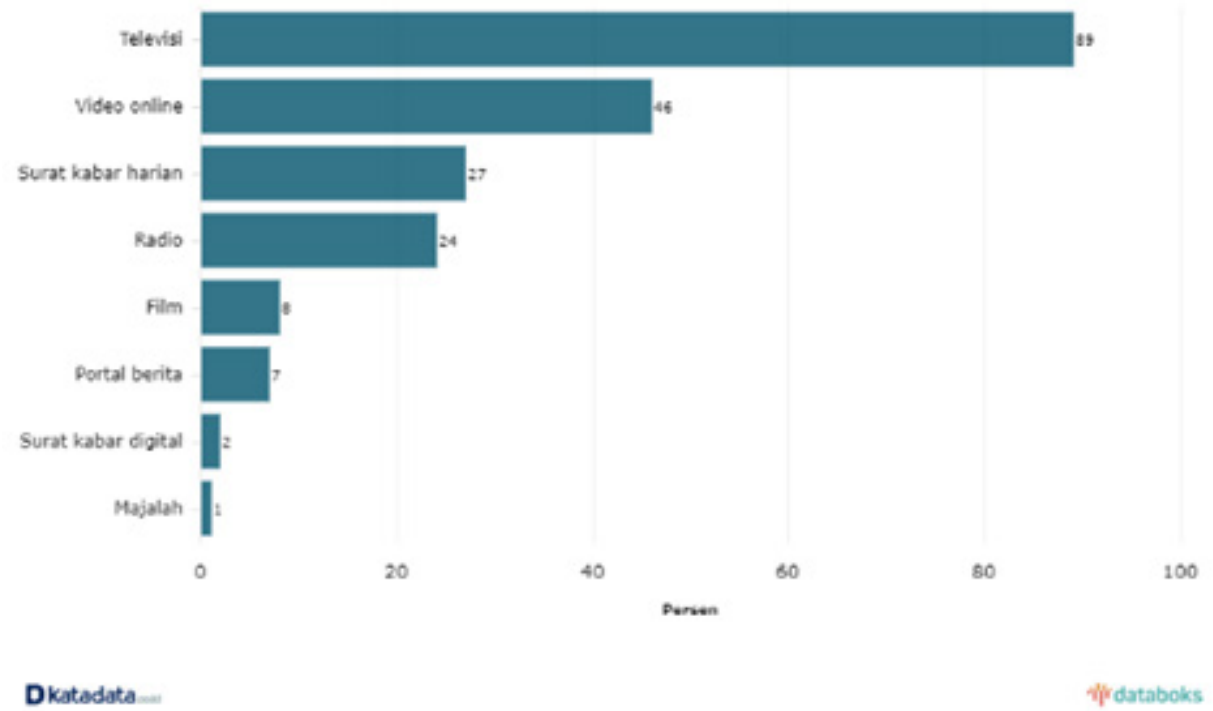


waktu tertentu dalam program televisi terhadap total penonton pada semua stasiun televisi (Kristanty, 2017).

Televisi merupakan media komunikasi massa, dalam Model Maletzke disebut bentuk dari setiap komunikasi untuk menyampaikan pernyataan secara terbuka melalui media penyebaran yang tidak langsung dan memiliki sifat satu arah kepada publik secara luas (Angela et al., 2019). Penelitian ini menggunakan Model Maletzke tersebut, relevan dengan komponen dalam komunikasi massa televisi, yaitu: 1) komunikator massa yaitu orang yang melakukan produksi sinetron; 2) pesan massa yang disampaikan melalui pesan-pesan sinetron; 3) media yang digunakan dalam penyampaian pesan yaitu televisi; dan 4) penerima yaitu penonton sinetron yang jumlahnya berubahubah karena komunikator menyampaikan pesan dari televisi secara tidak langsung. Televisi juga memiliki pengaruh terhadap individu. Pengaruh televisi telah banyak dipelajari dan dikonfirmasi kekuatan pengaruhnya terhadap publik. Terdapat beberapa pengaruh tayangan televisi yang telah dikaji oleh para peneliti dari berbagai negara, yang menyatakan televisi tidak hanya mempengaruhi perilaku dan dapat menghasilkan perilaku baru, tetapi juga berpengaruh terhadap pola perilaku (Moeller, 1996). Televisi juga disebut memiliki pengaruh kuat terhadap perkembangan anak-anak (Guru et al., 2013), perkembangan otak (Takeuchi et al., 2015), perkembangan bidang per-televisian (Peirce et al., 2012), perkembangan industri televisi (Simons, 2014), dan perkembangan sosio keagamaan (Siagian et al., 2016). Terdapat penelitian yang menunjukkan dampak positif dari tayangan televisi, diantaranya program televisi populer Master Chef. Program Master Chef memainkan peran penting dalam melengkapi dan mendukung langkahlangkah pemerintah yang bertujuan untuk mempromosikan pendidikan, pelatihan, dan bidang kejuruan di kalangan remaja (Pietro, 2016). Televisi pendidikan merupakan aset penting untuk pembelajaran informal anakanak selama masa prasekolah dan seterusnya (Anderson et al., 2012).

Penelitian-penelitian tersebut menunjukkan beberapa efek positif dari televisi. Hanya saja sejumlah riset lain mengambil sudut pandang yang berbeda dan menunjukkan hasil yang berbeda, seperti ada hubungan antara penggunaan televisi dengan isolasi dan kecemasan pada anak usia 4 sampai 6 tahun (Asghari et al., 2017). Sejumlah penelitian juga menyebutkan bahwa televisi memiliki pengaruh terhadap prestasi akademik dan penguasaan bahasa pada anak-anak pra-sekolah (Ahinda et al., 2014). Hal tersebut dibuktikan pada penelitian yang menyatakan bahwa remaja pemirsa TV dengan intensitas menonton yang 
rendah menunjukkan prestasi skolastik yang lebih tinggi daripada kelompok remaja pemirsa TV dengan intensitas menonton yang tinggi (Noor-ul-amin, 2013). Menonton televisi memiliki pengaruh yang cukup negatif terhadap prestasi akademik. Ini berarti semakin banyak siswa menghabiskan waktu menonton televisi, semakin sedikit nilai yang dicapai di sekolah (Kakamad et al., 2018).

Efek lain dari tayangan sinetron mengemuka berdasarkan penelitian tentang efek televisi dan sinetron bagi remaja. Penelitian tersebut menyebutkan bahwa serial drama televisi secara terus menerus dapat memperkuat gagasan ideal tentang standar kecantikan, bahwa seorang remaja harus memperhatikan penampilan seperti berpenampilan sangat feminin agar disukai. Hal tersebut menimbulkan seolah tidak ada ruang untuk gadis "cerdas" atau tipe gadis lainnya (Hendriyani et al., 2015). Remaja yang menonton drama televisi lebih banyak menunjukkan tingkat interaksi parasosial yang lebih tinggi, yang mengarah pada keyakinan romantis yang lebih kuat. Termasuk mengenai gaya keterikatan dan kecemasan dalam menjalin hubungan secara positif yang dikaitkan dengan menonton drama dan interaksi parasosial (Jin \& Kim, 2015). Lebih jauh terkait sinetron, disebutkan bahwa yang menonton drama di televisi memiliki gambaran tentang sebuah perasaan berupa rasa memiliki terhadap sekelompok pemirsa tertentu (perasaan istimewa), perasaan memiliki keluarga yang lebih besar (keterkaitan), memiliki kesamaan dengan pemirsa lain (rasa yang sama), atau sebagai sesuatu yang pasti berkontribusi untuk menambah unsur kesenangan dalam menonton fiksi di TV (Simons, 2015). Intinya, berdampak secara positif ataupun negatif, berpengaruh dengan skala dominan, moderat ataupun ringan, tayangan televisi memiliki dampak tersendiri bagi individu dan masyarakat.

Dampak televisi ini juga berlaku di Indonesia. Secara perlahan namun pasti, televisi ternyata mempengaruhi tren penelitian di Indonesia. Berbagai aspek televisi telah dikaji oleh sejumlah peneliti Indonesia dari berbagai bidang. Hal yang menarik adalah terdapat sejumlah sinetron popular di Indonesia yang mendapat perhatian dari para peneliti, sehingga menggerakkan untuk mengkaji tentang sebuah tayangan sinetron dari berbagai paradigma dan perspektif keilmuan. Penelitian ini merupakan penelitian atas penelitian tentang sinetron yang berbeda dengan penelitian terdahulu tentang desain visual Mustaqim et al. (2013). Penelitian atas penelitian memerlukan refleksi ketajaman atau kehati-hatian untuk menentukan dan menyumbangkan manfaat praktis bagi perjalanan suatu penelitian. Penelitian ini juga menggunakan Teori Berpikir Reflektif Dewey untuk merefleksikan berbagai teori, metode, 
dan bidang penelitian (Anwar et al., 2018) yang telah diteliti dari beragam aspek terkait sinetron popular di Indonesia yang memiliki jumlah riset terbanyak ditemukan yaitu: "Tukang bubur naik haji”, “Anak jalanan”, “Ganteng-ganteng serigala", dan "preman pensiun". Berdasarkan latar belakang tersebut, maka penelitian ini bertujuan untuk melakukan pemetaan hasil riset terkait empat sinetron popular di Indonesia, yang dikaitkan dengan tren riset pertahun, keberlangsungan dan perkembangan riset dalam periode tertentu, komparasi jenis publikasi atas hasil penelitian, serta topik riset yang dijadikan kata kunci oleh peneliti. Beberapa penelitian terdahulu telah mengkaji empat sinetron popular ini dengan menggunakan berbagai metode, namun sejauh ini belum ada riset yang melakukan pemetaan terhadap hasil penelitian yang telah dilakukan oleh para peneliti tersebut. Hal ini menjadi state of the art penelitian yang mendorong peneliti untuk berkontribusi secara teoretis maupun praktis bagi bidang pertelevisian.

\section{METODE PENELITIAN}

Penelitian ini menggunakan metode bibliometrik. Bibliometrik ini mengacu pada penerapan statistik secara teknis pada subjek literatur, sekaligus mempelajari pola komunikasi antara informasi yang terekam dengan penggunaan informasi yang potensial
(Harande, 2001). Beberapa penelitian terdahulu menyebutkan bahwa bibliometrik dimaksudkan untuk mengetahui tren penelitian yang berkaitan dengan topik tertentu. Ketersediaan informasi berupa pemetaan hasil penelitian membantu peneliti untuk mengarahkan perhatiannya pada topik kajian yang belum tergali (Mahameruaji et al., 2021). Kajian bibliometrik yang dilakukan secara komprehensif dapat mencakup pengungkapan tentang masalah dan hubungan yang lebih luas, serta menggambarkan peta riset dari suatu kajian (Ejsmont et al., 2020). Peta ini dapat digunakan sebagai bahan pengambilan keputusan terkait keberlanjutan kajian tersebut. Sebuah literatur menjelaskan bahwa salah satu indikator bibliometrik adalah penggunaan kata yang terkandung dalam dokumen. Indikator tersebut dihitung berdasarkan jumlah frekuensi munculnya kata dalam dokumen dan turunannya, bersamaan dengan indikator dari analisis Co-word (Farida et al., 2020).

Penelitian ini berupaya untuk mengetahui peta hasil riset terkait empat sinetron popular di Indonesia. Peneliti berupaya untuk mencari data tentang penelitian terkait objek yang dimaksud menggunakan Google scholar sebagai sumber data. Ekstraksi data dilakukan dengan menggunakan tools Publish or Perish. Pencarian data menggunakan queery judul empat sinetron yang memiliki jumlah riset terbanyak ditemukan yaitu "Anak Jalanan", 
“Tukang Bubur Naik Haji”, "Preman Pensiun”, dan "Ganteng-ganteng Serigala" (Tabel 1) pada kolom kata kunci.

Data selanjutnya diedit dan disesuaikan melalui Zotero. Termasuk menelusuri dan melengkapi data terkait tahun terbit, jenis publikasi, dan kata kunci. Peneliti juga berupaya mencari data sekunder melalui literatur untuk melengkapi data terkait gambaran empat sinetron popular di Indonesia yang menjadi objek penelitian. Pada tahap selanjutnya data divisualisasi melalui program Excel dan VOSViewer. Pada saat pemetaan melalui VOSviewer ditentukan minimum number of co-occurence a keyword adalah 4, sehingga menghasilkan 39 threshold. Langkah terakhir yang dilakukan peneliti adalah melakukan analisis yang dijadikan sebagai bahan penarikan kesimpulan.

\section{HASIL DAN PEMBAHASAN}

Berdasarkan penelusuran dokumen penelitian yang terindeks di Google Scholar, penelitian ini menemukan 123 penelitian tentang empat sinetron populer di Indonesia yang telah dilakukan oleh para peneliti sebelumnya (Tabel 1). Sinetron "Anak Jalanan" adalah sinetron yang paling banyak diteliti yakni sejumlah 44 riset, meskipun sinetron ini terbilang singkat karena tayang pada Oktober 2015 hingga Februari 2017 (1 tahun 4 bulan) dengan 810 episode. Jumlah penelitian tentang sinetron "Tukang Bubur Naik Haji” hanya menempati urutan dua dengan 36 penelitian, meskipun sinetron ini tayang bertahun-tahun, yakni mulai Mei 2018 hingga Februari 2017 dengan 2185 episode. Sinetron "Preman Pensiun" yang tayang pada tahun 2015-2021 menempati peringkat tiga dengan 25 riset, dan sinetron "Ganteng-Ganteng Serigala" yang tayang pada tahun 2014-2015 menempati peringkat empat dengan 18 riset.

Temuan penelitian ini menunjukkan bahwa rating and share dapat diasumsikan menjadi salah satu faktor pendorong para peneliti tertarik untuk melakukan penelitian tentang sinetron tertentu. Berdasarkan pengamatan yang dilakukan, sinetron "Anak Jalanan" adalah sinetron yang memiliki rating and share tertinggi dibandingkan tiga sinetron lainnya. Itu artinya sinetron ini digemari oleh masyarakat sehingga mungkin menjadi menarik bagi para peneliti untuk melakukan studi dengan berbagai pertanyaan penelitian dirancang.

Hasil penelitian ini juga menunjukkan bahwa banyaknya episode dan panjangnya masa tayang tidak menjadi pendorong utama bahwa peneliti banyak yang tertarik untuk melakukan penelitian tentang sinetron tertentu. Berdasarkan temuan ini, implikasinya adalah adanya potensi kesamaan topik riset yang dilakukan oleh para peneliti karena kecenderungan untuk meneliti 
Tabel 1 Pemetaan Berdasarkan Judul Sinetron dan Jumlah Riset yang Ditemukan

\begin{tabular}{lcccc}
\hline \multicolumn{1}{c}{ Judul Sinetron } & Masa Tayang & Jumlah Episode & $\begin{array}{c}\text { Rating \& Share } \\
\text { Tertinggi }\end{array}$ & $\begin{array}{c}\text { Jumlah Riset yang } \\
\text { Ditemukan }\end{array}$ \\
\hline Anak Jalanan & $2015-2017$ & 810 & $10.8 / 44$ & 44 \\
Tukang Bubur Naik Haji & $2012-2017$ & 2185 & $6.0 / 23.1$ & 36 \\
Preman Pensiun & $2015-2021$ & 185 & $3.9 / 20.6$ & 25 \\
Ganteng-ganteng Serigala & $2014-2015$ & 471 & $2.7 / 16.2$ & 18 \\
\hline \multicolumn{1}{c}{ Jumlah } & & & 123 \\
\hline
\end{tabular}

Sumber: Hasil Penelitian, 2021; Fahlevi, 2021

sinetron tertentu yang memiliki rating and share yang tinggi.

Hasil penelitian ini juga mengungkap keberlangsungan dan tren riset tentang masingmasing sinetron dari tahun ke tahun (Gambar 2). Sinetron "Tukang Bubur Naik Haji" pertama kali ditayangkan di televisi pada tahun 2012 dan berakhir tahun 2017. Dalam masa itu terdapat beberapa riset tentang sinetron ini yang dihasilkan oleh para peneliti. Pada tahun kedua penayangan (2013), terdapat tujuh penelitian tentang sinetron ini, dan mengalami kenaikan hingga $100 \%$ pada tahun ketiga (2014) yakni sejumlah 14 penelitian.

Tahun-tahun berikutnya, tren riset cenderung menurun yakni tujuh riset di tahun 2015, dua riset di tahun 2016, dan dua riset di tahun 2017. Penurunan tersebut wajar terjadi mengingat sinetron ini telah banyak diteliti oleh peneliti sebelumnya. Lebih lanjut, tayangan sinetron "Tukang Bubur Naik Haji” yang berakhir di tahun 2017 ternyata masih menarik bagi beberapa peneliti untuk melakukan penelitian. Terdapat empat penelitian tentang sinetron ini di tahun 2018 dan 2019.

Sinetron "Ganteng-Ganteng Serigala"

\section{KEBERLANGSUNGAN DAN PERKEMBANGAN RISET}

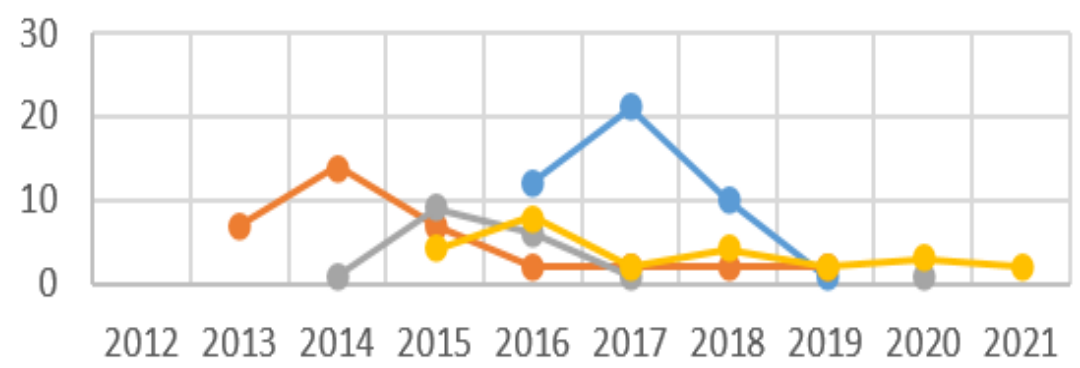

$\longrightarrow$-ANAK JALANAN

$\longrightarrow$-TUKANG BUBUR

- GANTENG SERIGALA

- PREMAN PENSIUN

Sumber: Hasil Penelitian, 2021

Gambar 2 Keberlangsungan dan Perkembangan Riset Tayangan Sinetron 
ditayangkan pada tahun 2014-2015. Di masa penayangan tersebut, terdapat beberapa penelitian yang dihasilkan oleh para peneliti tentang sinetron ini. Pada tahun pertama penayangan (2014), terdapat satu penelitian yang ditemukan, dan selanjutnya meningkat signifikan pada tahun kedua (2015) dengan sembilan penelitian. Tren penelitian tentang sinetron ini mulai menurun pada tahun (2016) dengan enam penelitian, dan menurun drastis tahun 2017 dengan satu penelitian saja. Fakta tersebut juga menjelaskan bahwa berakhirnya masa tayang sinetron ini, tidak menghalangi para peneliti untuk melakukan penelitian tentang sinetron ini. Pada tahun 2018-2019, memang tidak ditemukan penelitian yang membahas tentang sinetron ini, hingga akhirnya terdapat satu penelitian tentang "Ganteng-Ganteng Serigala" di tahun 2020.

Hasil penelitian ini juga menggambarkan tren riset tentang sinetron "Anak jalanan" yang tayang pada tahun 2015-2017. Sinetron "Anak Jalanan" yang bahkan masa tayangnya singkat ini cukup menarik para peneliti untuk melakukan penelitian. Dari proses penelusuran yang dilakukan, terdapat penelitian tentang sinetron ini pada tahun kedua penayangan (2016) sebanyak 12 penelitian, dan naik signifikan menjadi 21 penelitian di tahun ketiga penayangan (2017). Di tahun 2018, tren riset tentang sinetron ini masih berlanjut meskipun tayangan sinetronnya sudah berakhir, dan memang tren risetnya cenderung menurun. Terdapat 10 penelitian tentang sinetron ini yang ditemukan pada tahun 2018 , dan satu penelitian pada tahun 2019 .

Sinetron "Preman Pensiun" yang tayang pada tahun 2015-2021 dibagi dalam lima musim. Setiap musimnya ada beberapa episode yang ditayangkan. Penelitian tentang sinetron ini mulai muncul pada tahun pertama penayangan (2015) yakni sejumlah empat penelitian. Tren riset tentang sinetron ini naik $100 \%$ di tahun kedua penayangan (2016) yakni sejumlah 8 penelitian. Penurunan tren riset tentang sinetron ini menurun di tahun ketiga penayangan (2017) yakni sejumlah dua penelitian, dan cenderung fluktuatif di tahun-tahun berikutnya. Terdapat empat penelitian yang ditemukan pada tahun 2018, dua penelitian pada tahun 2019, tiga penelitian pada tahun 2020, dan dua penelitian pada tahun 2021 .

Hasil penelitian ini mengungkap bahwa tren kenaikan penelitian tentang keempat sinetron ini terjadi di tahun kedua atau ketiga penayangan sinetron tersebut, dan cenderung menurun setelah tahun kedua dan ketiga. Berakhirnya masa tayang sinetron tidak menghentikan keberlangsungan tren riset terkait sinetron tersebut setidaknya dua tahun setelah tayangan sinetron berakhir. Tiga sinetron yang populer di Indonesia yakni “Tukang Bubur Naik 
Haji”, "Ganteng-Ganteng Serigala", dan "Anak Jalanan" tetap menarik bagi peneliti untuk melakukan penelitian tentang masing-masing sinetron tersebut meskipun trennya cenderung menurun.

Berdasarkan temuan penelitian ini, implikasinya adalah adanya peningkatan jumlah kajian yang terjadi di tahun kedua atau ketiga penayangan keempat sinetron popular di Indonesia dikhawatirkan mengarah kepada tren yang bersifat temporer. Peningkatan riset sejenis di tahun-tahun yang sama juga dapat berimplikasi pada potensi kurangnya aspek kebaruan dari suatu penelitian. Hal ini karena adanya kemungkinan penelitian dilakukan dalam waktu bersamaan sehingga tidak dapat mengetahui satu sama lain terkait aspek kebaruan yang akan ditonjolkan oleh masingmasing peneliti dalam penelitiannya terkait sinetron tertentu.

Berdasarkan penelusuran yang dilakukan, penelitian ini juga memetakan hasil riset tentang empat sinetron di Indonesia berdasarkan jenis publikasinya (Gambar 3). Dari keempat sinetron, terdapat 54 penelitian yang terpublikasi sebagai artikel dalam sebuah jurnal, dan terdapat 69 penelitian yang terpublikasi sebagai skripsi di repository database milik perguruan tinggi yang terindeks Google Scholar. Jenis publikasi skripsi lebih banyak dibandingkan

\section{PERBANDINGAN JENIS PUBLIKASI}

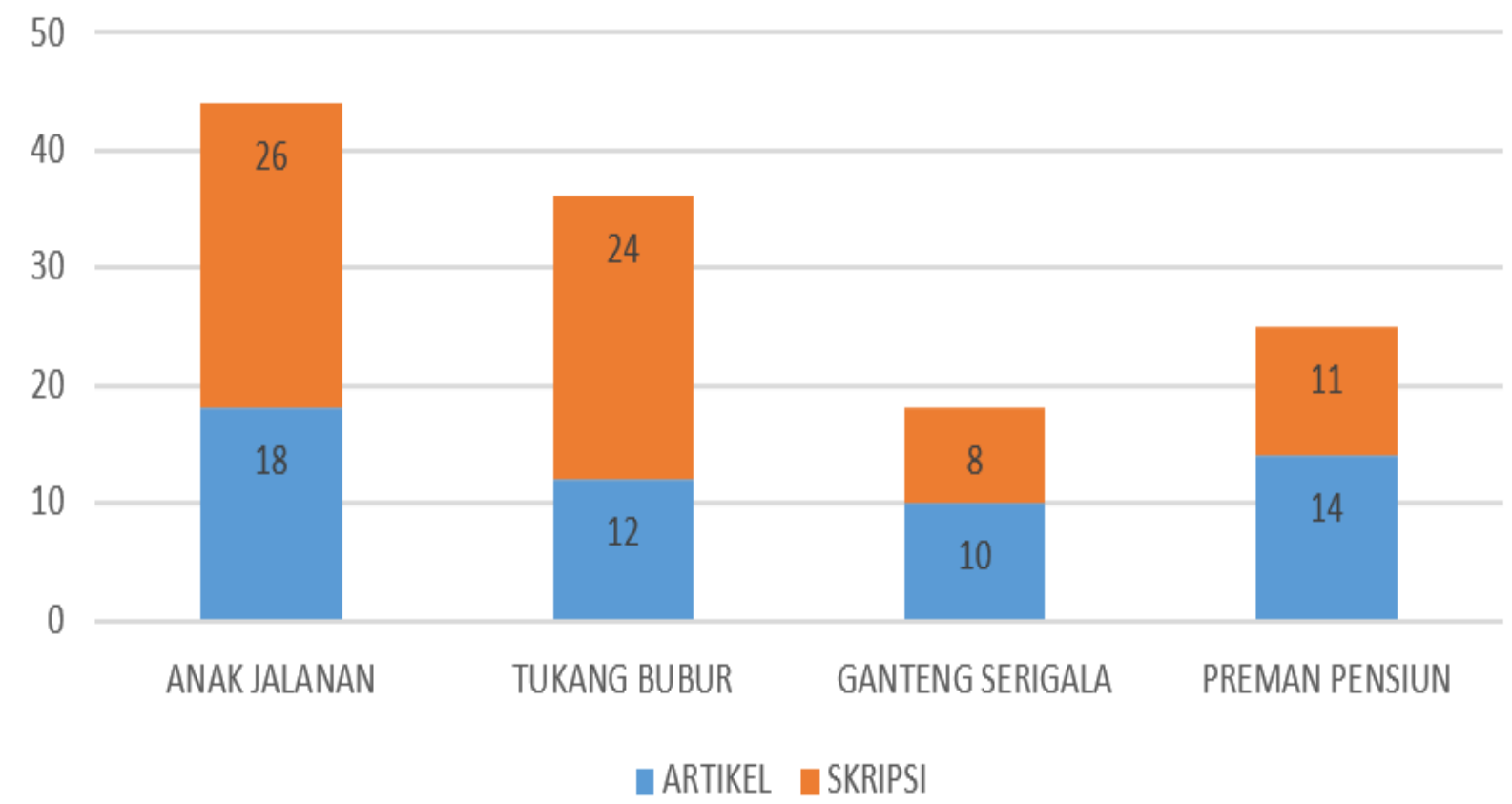

Sumber: Hasil Penelitian, 2021

\section{Gambar 3 Perbandingan Jenis Publikasi Riset Tayangan Sinetron}


yang publikasi artikel jurnal. Implikasinya adalah penelitian yang terkait dengan empat sinetron ini cenderung dilakukan oleh kalangan mahasiswa S1 sebagai kewajiban yang harus dipenuhi untuk mendapatkan gelar sarjana dari perguruan tinggi, meskipun ada kemungkinan hasil riset skripsinya juga dapat dipublikasikan dalam bentuk artikel jurnal.

Lebih detil, terdapat 26 penelitian berbentuk skripsi dan 18penelitian berbentuk artikel jurnal yang meneliti tentang sinetron "Anak Jalanan". Sinetron "Tukang Bubur Naik Haji” diteliti sebanyak 36 kali, dengan rincian 24 penelitian berbentuk skripsi dan 12 penelitian berbentuk artikel jurnal. Selanjutnya, terdapat delapan penelitian berbentuk skripsi yang membahas sinetron "Ganteng-Ganteng Serigala", dan 10 penelitian yang berbentuk artikel jurnal. Pada sinetron "Preman Pensiun" terdapat 11 penelitian dalam bentuk skripsi dan 14 penelitian dalam bentuk artikel jurnal. Sinetron "Anak Jalanan" dan "Tukang Bubur Naik Haji” menjadi sinetron yang paling banyak diteliti dalam bentuk skripsi dibandingkan artikel jurnal.

Berdasarkan visualisasi kata kunci yang terdapat dalam 123 penelitian terkait empat sinetron di Indonesia, penelitian ini mengidentifikasi adanya enam klaster berkaitan dengan hasil penelitian keempat sinetron dengan 39 kata kunci atau konsep. Gambar 4 adalah visualisasi dari klaster-klaster yang

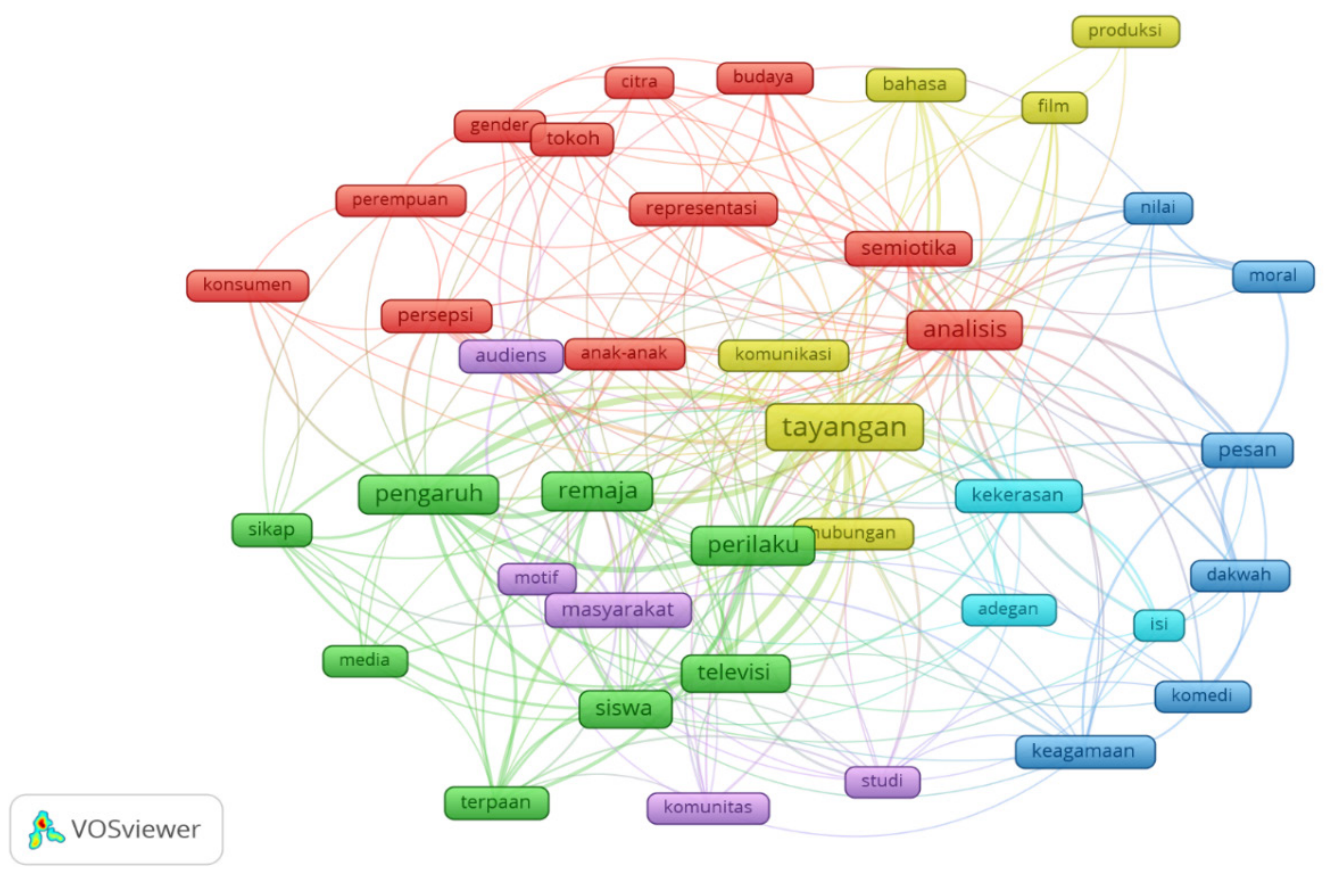

Sumber: Hasil Penelitian, 2021

Gambar 4 Visualisasi Kata-kata Kunci atau Konsep dalam Riset Tayangan Sinetron 
diolah menggunakan VOSviewer dengan membedakan warna blok untuk masing-masing klaster. Masing-masing klaster telah memiliki kekhasannya sendiri, namun satu konsep dalam satu klaster bisa saja terhubung dengan klaster yang lain.

Lebih lanjut, klasterisasi ini bertujuan untuk memberikan gambaran bagi peneliti selanjutnya dalam menganalisis konsep-konsep atau kata kunci tertentu terkait riset tayangan sinetron atau serial drama di Indonesia. Semakin besar blok dari sebuah kata kunci atau konsep, semakin sering juga konsep atau kata kunci itu dibahas oleh peneliti sebelumnya. Masing-masing klaster memiliki korelasi antar kata kunci popular yang digunakan pada setiap riset tayangan atau serial drama Indonesia. Dari visualisasi klaster ini, peneliti selanjutnya juga dapat melihat posisi riset mereka di tengah risetriset yang telah ada sebelumnya, apakah berbeda atau cenderung sama. Peneliti selanjutnya dapat melihat kecenderungan masing-masing klaster sebelum melakukan penelitian tentang tayangan sinetron

Konsep atau kata kunci yang terkait pada klaster pertama yang berwarna hijau adalah pengaruh, perilaku, sikap, remaja, dan televisi. Klaster ini merepresentasikan penelitianpenelitian tentang pengaruh terpaan media atau televisi terhadap sikap dan perilaku, dalam konteks ini adalah tayangan sinetron di televisi.
Sementara itu klaster kedua yang berwarna merah menekankan pada konsep atau kunci analisis, semiotika, representasi, dan budaya. Klaster ini merepresentasikan penelitianpenelitian yang menggunakan analisis semiotika untuk memahami tayangan-tayangan sinetron di televisi.

Pada klaster ketiga yang berwarna kuning, konsep atau kata kuncinya adalah tayangan, komunikasi, produksi, dan film. Klaster ini bisa jadi merepresentasikan topik-topik riset yang berkaitan dengan tayangan atau produksi film sebagai produk komunikasi. Klaster keempat yang berwarna ungu berfokus pada konsep atau kata kunci motif, masyarakat, audien. Klaster ini mewakili topik-topik riset yang berfokus meneliti tentang motif audiens (masyarakat atau komunitas) dalam menonton tayangan sinetron.

Dalam kasus klaster kelima yang berwarna biru muda, konsep atau kata kunci yang muncul adalah isi, adegan, dan kekerasan. Klaster ini merepresentasikan riset yang fokus mengkaji adegan dalam tayangan sinetron seperti kekerasan. Kemudian, untuk klaster keenam yang berwarna biru tua, konsep atau kata kuncinya adalah pesan, moral, dakwah, komedi, keagamaan. Klaster ini merepresentasikan risetriset terdahulu yang membahas tentang pesan moral atau nilai yang terkandung dalam sebuah tayangan sinetron seperti nilai keagamaan, atau bahkan pesan yang bernuansa komedi. 
Bagi peneliti yang ingin membahas topik tayangan sinetron, peta klasterisasi ini membantu peneliti mengaitkan konsep-konsep yang memang terkait. Misalnya, saat peneliti selanjutnya memilih klaster pertama, titik awal yang perlu diperhatikan dalam tinjauan pustaka adalah konsep pengaruh terpaan media atau televisi terhadap perilaku. Selanjutnya peneliti, juga dapat mengeksplorasi literatur terkait di sumber-sumber atau portal referensi akademik dengan melakukan pencarian menggunakan kata kunci yang berkaitan dengan klaster pertama yaitu perilaku, sikap, remaja, dan siswa.

Klaster pertama, terkait dengan pengaruh terpaan media, artikel yang relevan sebagai referensi misalnya yang ditulis oleh Bahari et al. (2017).Penelitiantersebutmencobamenjelaskan atau menguji hipotesis bahwa tayangan sinetron "Anak Jalanan" mempengaruhi beberapa dimensi dari anak-anak di antaranya kognitif, afektif, dan behavioral. Hasilnya menunjukkan bahwa tayangan sinetron "Anak Jalanan" tidak berpengaruh secara signifikan dalam memengaruhi perilaku anak. Lebih lanjut, sebenarnya riset semacam ini juga telah banyak dilakukan oleh para peneliti yang bertujuan menguji pengaruh terpaan tayangan sinetron terhadap sikap atau perilaku individu tertentu.

Klaster kedua, analisis semiotika dapat dilakukan pada tayangan sinetron. Lasani (2015) telah melakukan eksplorasi terkait identitas remaja yang direpresentasikan dalam tayangan sinetron Ganteng-Ganteng Serigala. Analisis semiotika diterapkan untuk mengungkap representasi identitas remaja dalam sebuah sinetron. Hasilnya, penelitian ini mengungkap bahwa penampilan fisik adalah representasi utama identitas seorang remaja. Selain itu, identitas remaja juga teridentifikasi dari kelompok sosial dan karakter seorang remaja yang ditampilkan dalam sinetron tersebut.

Klaster ketiga berkaitan dengan analisis produksi tayangan televisi, dan contoh risetnya seperti yang dilakukan oleh Khairiyah (2016). Penelitian tersebut berupaya mengidentifikasi proses produksi dan hambatan yang dialami dalam pembuatan tayangan sinetron "Tukang Bubur Naik Haji”. Dari penelitian tersebut, salah satunya didapatkan temuan mengenai tahapan produksi yang diterapkan oleh tim yang terdiri dari enam tahapan yakni tahap penyiapan komponen komunikasi, tahap pemilihan realitas, tahap pembingkaian skenario, tahap pembentukan realitasi subjektif, tahap pengemasan realitas simbolik, tahap penetapan realitas objektif. Hal ini mungkin menjadi fokus riset yang menarik bagi peneliti selanjutnya yang tertarik untuk meneliti produksi tayangan televisi. Hal semacam ini juga berlaku untuk para peneliti yang coba untuk fokus pada klaster keempat, kelima, dan keenam.

Berdasarkan klasterisasi ini, penelitian ini 
berimplikasi pada dugaan adanya kesamaan minat, ide, dan penggunaan metode dalam risetriset terkait tayangan sinetron. Hal ini perlu diperhatikan oleh peneliti selanjutnya sebagai antisipasi agar tidak terjadi pengurangan nilai originalitas dan aksiologi dari sebuah karya ilmiah. Peta visualisasi tersebut menunjukkan terdapat hubungan atau keterkaitan antara kata kunci dengan representasi dari sebuah penelitian yang dilakukan. Berdasarkan 39 kata kunci dengan link paling kuat tersebut, dapat diketahui bahwa penelitian atau riset mengenai tayangan sinetron atau serial drama di Indonesia sering dilakukan.

Tren kenaikan jumlah riset terkait empat sinetron populer di Indonesia, rerata mencapai puncaknya pada tahun kedua. Artinya minat untuk melakukan riset terkait sinetron empat tersebut mulai tinggi setelah melihat perkembangan minat masyarakat untuk menonton dan rating dari sinetron tersebut. Sinetron "Tukang bubur naik haji" sempat meraih Panasonic Gobel Awards 2013, 2014, dan 2015 sebagai Drama Seri Terfavorit. Begitu juga dengan sinetron "Preman pensiun" dinobatkan sebagai sinetron terpilih versi Festival Film Bandung 2015. Keberhasilan program siaran tersebut merupakan hasil tolak ukur dari konsep rating dan share sinetron yang diterapkan berbagai stasiun televisi untuk mengukur kelayakan nilai jual (Enga, 2016).
Rating dan share yang tinggi, serta acara yang memiliki daya tarik budaya, sosial, keagamaan pada kedua sinetron tersebut mampu membuat keduanya memuncaki rating sinetron, sekaligus menarik perhatian akademisi untuk melakukan riset.

Alur cerita kedua sinetron dianggap lekat dengan kehidupan masyarakat seharihari, sekaligus mencerminkan adat kebiasaan sekelompok masyarakat. Karakter unik individu yang dilakonkan tokoh tertentu pun dianggap cerminan karakter individu yang dianggap ada dalam realitas sosial. Hal ini sejalan dengan pemikiran bahwa popularitas drama dihasilkan oleh keterlibatan penonton dengan narasi yang diangkat dalam drama tersebut (D. K. Kim et al., 2009).

Popuritas drama dengan kekuatan selebriti telah diakui dalam berbagai penelitian bidang pemasaran dan periklanan. Pengenalan selebriti sebagai endorser diharapkan dapat meningkatkan kredibilitas yang menghasilkan penilaian yang lebih tinggi terhadap suatu produk (S. Kim et al., 2019). Berdasarkan hal tersebut, maka tak mengherankan jika Citra Kirana yang memerankan salah tokoh utama perempuan dalam sinetron tersebut menjadi endorser dan dianggap mampu meningkatkan brand image dari suatu produk fashion (Jushermi et al., 2017).

Popularitas selebritis dalam sebuah 
tayangan televisi yang menjadi endorser sebuah produk tertentu, juga dapat mempengaruhi selera dan keinginan anak-anak untuk memiliki atau membeli produk yang di-endors oleh idolanya. Terlihat bahwa televisi memiliki pengaruh yang kuat pada konsumen di antaranya adalah konsumen anak-anak (Guru et al., 2013). Hal ini terlihat bahwa komunikasi massa Maletzke membuktikan komunikasi yang terbentuk terbuka kepada siapa saja dan tidak secara langsung, namun satu arah kepada publik (Angela \& Winduwati, 2019). Pada penelitian ini komponen komunikasi massa tersebut terlihat bahwa: 1) komunikator massa memproduksi pesan adalah selebritis idola yang populer; 2) pesan yang disampaikan yaitu anak-anak; 3) Media yang digunakan antara komunikator dan penerima adalah televisi; dan 4) penerima pesan harus menyeleksi dan mengontrol berbagai pesan terkait endors produk idola agar tidak menciptakan pola perilaku anak yang konsumtif. Hal tersebut menjadikan seseorang tidak hanya menjadi penonton setia sebuah tayangan sinetron, namun sekaligus menjadi konsumen setia dari produk yang menggunakan idolanya sebagai bintang iklan.

Tema utama, naskah yang bagus, pilihan artis yang tepat dan lagu tema yang sesuai dalam drama yang berkontribusi pada popularitas tinggi dan secara keseluruhan meninggalkan dampak bagi industri TV Malaysia (Ling, 2018).
Sebagian dari faktor-faktor tersebutlah yang dimiliki oleh empat sinetron dan mengantarkan program tersebut ke puncak rating persinetronan di Indonesia.

Keempat sinetron ini dianggap memiliki alur cerita yang baik dan mampu mewakili kehidupan sehari-hari masyarakat yang diangkat dalam naskah. Lapisan masyarakat yang diangkat dalam keempat sinetron ini mencerminkan budaya yang khas dan mampu menimbulkan kedekatan psikologis dan geografis penonton. Begitu juga dengan pemilihan pemain. Aktor dan aktris yang melakonkan tokoh tertentu relatif sudah dikenal dan memiliki reputasi tertentu dalam dunia sinetron. Terdapat pula faktor keindahan visual secara fisik dari para pelakon sebagai daya tarik tersendiri.

Berbeda dengan sinetron "Tukang bubur naik haji”, pada sinetron Anak jalanan, Ganteng-ganteng serigala, dan preman pensiun, cenderung menampilkan adegan perkelahian ataupun kekerasan dalam level dan konteks tertentu. Tingkat keparahan kekerasan yang mendominasi narasi sebuah tayangan merupakan akibat dari penggunaan daya tarik rasa takut yang dinilai memiliki nilai strategis oleh produsen (Yue, 2019). Intinya, kekerasan yang ditampilkan pada sebuah tayangan, dimaksudkan untuk menjadi daya tarik dengan cara meningkatkan ketegangan di dalam diri 
penonton.

Tayangan serial berkontribusi pada teori komunikasi dengan menekankan pada aspek pergeseran pendidikan hiburan di lanskap media transnasional dan signifikansi analitis yang berpengaruh dalam menganalisis budaya populer dan komunikasi strategis (Jaber \& Kraidy, 2020). Budaya populer tidak hanya diperoleh penonton kalangan remaja dari televisi, namun juga dari internet. Terdapat trend di beberapa media sosial berupa kemunculan akun yang secara khusus membahas tentang sebuah sinetron atau pun fanbase dari pasangan yang menjadi tokoh utama. Kemunculan akun semacam ini turut mengangkat popularitas sebuah sinetron, terutama jika terdapat pro dan kontra di kalangan komentator akun tersebut. Fenomena semacam ini dapat dikategorikan sebagai salah satu perkembangan budaya populer.

Perkembangan budaya populer ini merupakan hal yang sudah semestinya terjadi, namun patut diwaspadai. Media televisi merupakan salah satu alat persuasi, begitu juga dengan internet. Kemampuan persuasi kedua alat ini dapat berdampak terhadap perubahan kebiasaan dan gaya hidup masyarakat. Salah satu kebiasaan masyarakat yang dapat dipengaruhi televisi dan internet adalah kebiasaan menonton televisi yang kurang terkendali. Kurangnya kemampuan pengendalian diri dari aspek lama nya waktu menonton sering dijumpai pada kelompok anak-anak.Mengingat anak-anak yang tidak memiliki komputer menghabiskan lebih banyak waktu untuk menonton televisi (Asghari et al., 2017), maka diperlukan peran orangtua untuk dapat mengawasi durasi dan jenis tontonan yang dikonsumsi anak-anak.

Pengawasan ini menjadi penting, sebab terdapat beberapa riset yang telah mengaitkan intensitas menonton televisi yang berdampak negatif pada anak-anak. Terdapat penelitian yang menyebutkan ada pengaruh yang signifikan antara intensitas menonton drama televisi terhadap prestasi belajar siswa (Himawan et al., 2017), dan terakhir semakin banyak siswa menghabiskan waktumenonton televisi, semakin sedikit rendah nilai yang dicapai (Kakamad \& Fatah, 2018). Sebaiknya orangtua mulai mengoptimalkan perannya dalam mengawasi intensitas anak dalam menonton televisi. Orangtua juga harus mempertimbangkan secara teliti dan seksama terkait tayangan sinetron yang ditonton untuk anak-anak. Pengaruh tayangan sinetron juga dapat merubah persepsi individu dalam memaknai entitas dalam kehidupan nyata dengan mengacu pada realita semu yang ditampilkan dalam serial drama, misalnya penilaian tentang kelas sosial. Hirarki sosial yang terbentuk dalam produksi sinetron komersial sebagian besar merupakan hasil persepsi tentang jenis pekerjaan sebagai 
kategori utama dalam melakukan klasifikasi kelas sosial (Myutel, 2017). Artinya, seolaholah kelas sosial diukur dari jenis pekerjaan. Hal ini tentu menjadi keliru jika penghargaan terhadap sebuah jenis pekerjaan dikaitkan dengan prestise semata.

Penelitian ini relevan dengan penelitian yang dilakukan oleh Anwar dan Sofiyan (2018) dengan langkah-langkah berpikir reflektif Dewey, terdiri dari: 1) mengidentifikasi masalah yaitu banyaknya penelitian bertema sinetron yang kurang memiliki kebaruan; 2) membatasi dan merumuskan masalah tentang 4 sinetron yang banyak diteliti dengan alasan rating dan share tinggi; 3) mengajukan solusi pemecahan masalah sebagai alternatif yaitu dilakukan pemetaan tema penelitian sinetron melalui visualisasi; dan 4) mengumpulkan data dari Google Scholar tentang penelitian bertema sinetron untuk mengembangkan ide penelitian lanjutan sehingga dapat memecahkan masalah tentang kesamaan penelitian.

Terlepas dari berbagai dampaknya, sinetron populer ternyata telah menarik perhatian peneliti di Indonesia, baik peneliti yang tengah melakukan pembuatan laporan akhir studi maupun skema riset yang lain. Berdasarkan trend riset terhadap empat sinetron populer di Indonesia tersebut dapat diketahui bahwa terdapat kecenderungan adanya kesamaan antara tiap kajian jika ditinjau dari aspek periodesasi dilakukan kegiatan riset tersebut, jenis output publikasi, maupun tema yang diangkat sebagai fokus penelitian, serta konsep-konsep yang dijadikan landasan dan desain penelitian.

Similiaritas ini, mendorong peneliti untuk merekomendasikan agar para peneliti tidak terjebak untuk mengusung tema klasik yang mengurangi nilai originalitas dan kontribusi penelitian. Selain itu, similiaritas tema dikhawatirkan akan membuat adanya similiaritas penggunaan metode yang membuat perkembangan metode riset terkait tayangan drama di televisi berjalan di tempat. Mengangkat tema yang memiliki nilai aktualitas memang penting, namun motif untuk melakukan kajian yang memberi dampak nyata bagi perkembangan ilmu pengetahuan dan kemaslahatan bagi masyarakat, jauh lebih utama.

\section{SIMPULAN}

Berdasarkan hasil berpikir reflektif, penelitian ini menemukan bahwa risetriset yang terindeks di Google Scholar yang berkaitan dengan empat tayangan sinetron di Indonesia paling banyak adalah penelitian tentang sinetron "Anak Jalanan", diikuti “Tukang Bubur Naik Haji”, "Preman Pensiun”, dan "Ganteng-ganteng Serigala". Penelitian ini menemukan bahwa tingginya rating dan share 
sebuah sinetron berkaitan dengan banyaknya jumlah riset yang dilakukan tentang sinetron tertentu. Penelitian ini juga menemukan kenaikan tren penelitian terjadi di tahun kedua atau ketiga penayangan sebuah sinetron, dan cenderung menurun setelah tahun kedua dan ketiga penayangan. Lebih lanjut, berakhirnya masa tayang sinetron tidak menghentikan keberlangsungan tren riset terkait sinetron tersebut setidaknya dua tahun setelah tayangan sinetron berakhir.

Temuan lainnya adalah terdapat 6 klaster dari konsep atau kata kunci yang berkaitan dengan riset-riset yang sudah dilakukan sebelumnya tentang empat sinetron di Indonesia. Klaster pertama berkaitan dengan pengaruh, perilaku, sikap, remaja, dan televisi.

Klaster kedua berkaitan dengan analisis, semiotika, representasi, dan budaya. Klaster ketiga berkaitan dengan tayangan, komunikasi, produksi, dan film. Klaster empat berkaitan dengan motif, masyarakat, dan audien. Klaster kelima berkaitan dengan isi, adegan, dan kekerasan. Terakhir, klaster keenam berkaitan dengan pesan, moral, dakwah, komedi, dan keagamaan.

Temuan penelitian ini menghasilkan beberapa implikasi di antaranya adalah adanya potensi kesamaan topik riset yang dilakukan oleh para peneliti karena kecenderungan untuk meneliti sinetron tertentu yang memiliki rating and share yang tinggi, adanya peningkatan jumlah kajian yang terjadi di tahun kedua atau ketiga penayangan keempat sinetron popular di Indonesia dikhawatirkan mengarah kepada tren yang bersifat temporer. Peningkatan riset sejenis di tahun-tahun yang sama juga dapat berimplikasi pada potensi kurangnya aspek kebaruan dari suatu penelitian karena satu sama lain belum mengetahui terkait aspek kebaruan yang akan ditonjolkan oleh masing-masing peneliti dalam penelitiannya terkait sinetron tertentu. Penelitian ini juga memberikan kebaruan tentang penelitian atas penelitian bertema sinetron yang berdampak kurang mendidik bagi masyarakat, melalu tahaptahap berpikir reflektif, yaitu: 1) identifikasi masalah terkait tema penelitian sinetron yang kurang memiliki kebaruan; 2) batasan dan rumusan masalah tentang penelitian sinetron yang memiliki rating dan share tinggi; 3) solusi pemecahan masalah berupa pemetaan tema penelitian sinetron melalui visualisasi; dan 4) pengumpulan data dari Google Scholar tentang penelitian bertema sinetron untuk mengembangkan ide penelitian lanjutan sehingga dapat mengurangi masalah kesamaan penelitian.

Hasil penelitian ini diharapkan dapat memberikan gambaran perkembangan riset terkait tayangan sinetron populer di Indonesia. Gambaran perkembangan riset terkait tayangan 
sinetron populer di Indonesia ini dapat dimanfaatkan untuk dasar pertimbangan bagi akademisi dalam menangkap fenomena yang layak untuk dijadikan topik penelitian. Peneliti selanjutnya dapat melihat aspek atau konsep mana yang sekiranya belum banyak dibahas dalam penelitian sebuah tayangan sinetron di Indonesia.

Penelitian ini diharapkan dapat membantu peneliti selanjutnya untuk mendudukkan risetnya sebagai riset yang memiliki kekhasan tertentu dalam menonjolkan aspek kebaruan di tengah riset-riset tayangan sinetron yang telah dilakukan oleh peneliti sebelumnya. Bagi praktisi produksi tayangan televisi, hasil penelitian ini dapat dijadikan sebagai informasi bahwa hasil karya pekerja layar kaca tidak hanya dapat meraih popularitas di kalangan penonton, namun juga menarik perhatian masyarakat akademisi.

\section{DAFTAR PUSTAKA}

Ahinda, A. A., Murundu, Z. O., Okwara, M. O., Odongo, C., \& Okutoyi, J. (2014). Effects of Television on Academic Performance and Languages Acquisition of PreSchool Children. International Journal of Education and Research, 2(11), 493-502.

Anderson, D. R., Lavigne, H. J., \& Hanson, K. G. (2012). The Educational Impact Of Television. The International Encyclopedia of Media Studies, December. https://doi. org/10.1002/9781444361506.wbiems134

Angela, M., \& Winduwati, S. (2019).
Representasi Kemiskinan dalam Film Korea Selatan (Analisis Semiotika Model Saussure pada Film Parasite). Koneksi, 3(2), 478-484. https://doi.org/10.24912/ kn.v3i2.6480

Anwar, \& Sofiyan. (2018). Teoritik tentang Berpikir Reflektif Siswa dalam Pengajuan Masalah Matematis. Jurnal Numeracy, 5(1), 91-101.

Asghari, M., Karimzadeh, M., \& Teymouri, R. (2017). Relationship between using television and behavioral problems of preschool children. Iranian Rehabilitation Journal, 15(4), 325-332. https://doi. org/10.29252/nrip.irj.15.4.325

Bahari, D. W., Ratnamulyani, I. A., \& Kusumadinata, A. A. (2017). Pengaruh Tayangan Sinetron Anak Jalanan Terhadap Perilaku Anak. Jurnal Komunikatio, 3(1), 1-8. https://doi.org/10.30997/jk.v3i1.845

Ejsmont, K., Gladysz, B., \& Kluczek, A. (2020). Impact of industry 4.0 on sustainabilitybibliometric literature review. Sustainability (Switzerland), 12(14). https://doi.org/10.3390/su12145650

Enga, A. H. P. (2016). Komodifikasi Pernikahan "MenujuJanjiSuci"diTransTV(Pernikahan Raffi Ahmad dan Nagita Slavina). Jurnal Interaksi, 5(2), 177-186. https://doi. org/10.14710/interaksi.5.2.177-186

Fahlevi, S. I. (2021). 10 Sinetron dengan Rating Tinggi Sepanjang Masa, Ikatan Cinta Terbaik. Celebrities.id.

Farida, N., \& Firmansyah, A. H. (2020). Analisis Bibliometrik Berdasarkan Pendekatan CoWord: Kecenderungan Penelitian Kearsipan di Jurnal Khazanah: Jurnal Pengembangan Kearsipan dan Journal of The Archives and Records Association, Tahun 20162019. Khazanah: Jurnal Pengembangan Kearsipan., 13(2), 91-109. 
Guru, B. P. M. C., Nabi,A., \& Raslana, R. (2013). Role of Television in Child Development. Journal of Mass Communication \& Journalism, 03(03). https://doi. org/10.4172/2165-7912.1000153

Harande, Y. (2001). Productivity and Collaboration: an Investigation of the Relationship Using the Literature of Technology. Libri, 51(2), 124-127. https:// doi.org/doi:10.1515/libr.2001.124

Hendriyani, \& Guntarto, B. (2015). Representation of Beauty on Indonesian Teenagers' Television Drama Series. The Indonesian Journal of Communication Studies, 08(1).

Himawan, A. A., Basori, B., \& Adi Sucipto, T. L. (2017). Social Media Influence and Intensity of Watching Television Drama on Achievement of Students. IJIE (Indonesian Journal of Informatics Education), 1(2), 95. https://doi.org/10.20961/ijie.v1i2.11334

Indrajati, S. F., \& Ruliana, P. (2020). Strategi Program Acara the Newsroom Dalam Meningkatkan Rating Program. Medium, 8(1), 66-77. https://doi.org/10.25299/ medium.2020.vol8(1).4841

Jaber, H., \& Kraidy, M. M. (2020). The Geopolitics of Television Drama and the "Global War on Terror": Gharabeeb Soud Against Islamic State. International Journal of Communication, 14, 1868-1887.

Jin, B., \& Kim, J. (2015). Television Drama Viewing and Romantic Beliefs: Considering Parasocial Interaction and Attachment Style. International Journal of Humanities and Social Science, 5(10), 51-60.

Jushermi, Marhadi, \& Abidin, I. R. (2017). Analyzing the Influence of Celebrity Endorser Citra Kirana and Product Placement of Elzatta at Tukang Bubur Naik Haji The Series Cinema to Brand
Image and Brand Equity. Applied Science and Technology, 1(1), 588-591. http:// www.estech.org/index.php/IJSAT/article/ view/102

Kakamad, K. K., \& Fatah, A. H. (2018). The Relationship between Watching Television and Academic Achievement in 9th Graders Students Karwan. Information Management and Business Review, 10(1), 2499-2508.

Khairiyah, S. N. (2016). Analisis Produksi Terhadap Program Sinetron Tukang Bubur Naik Haji The Series (Episode 402 Dan 403). Universitas Islam Negeri Syarif Hidayatullah Jakarta.

Kim, D. K., Singhal, A., Hanaki, T., Dunn, J., Chitnis, K., \&Han, M. W. (2009). Television drama, narrative engagement and audience buyingbehavior:Theeffects ofWinter sonata in Japan. International Communication Gazette, 71(7), 595-611. https://doi. org/10.1177/1748048509341894

Kim, S., Kim, S. (Sam), \& Han, H. (2019). Effects of TV drama celebrities on national image and behavioral intention. Asia Pacific Journal of Tourism Research, 24(3), 233-249. https://doi.org/10.1080/1094166 5.2018 .1557718

Kristanty, S. (2017). Pengemasan Talk Show dalam Perspektif Manajemen Penyiaran Televisi (Studi Kasus pada Program "Polemik On TV di INews TV, Jakarta untuk meningkatkan Rating dan Share). Inter Komunika, 2(1), 47-60.

Lasani, P. U. (2015). Representasi Identitas Remaja Dalam Sinetron Ganteng-Ganteng Serigala Returns. Universitas Airlangga.

Ling, L. Y. (2018). The Popularity of Asian Drama Series on Malaysian Television. International Journal of Engineering \& Technology, 7(3.21), 470. https://doi. 
org/10.14419/ijet.v7i3.21.17215

Mahameruaji, J. N., Permana, R. S. M., Hafiar, H., \& Rahmawan, D. (2021). SOURCE AND MANAGEMENT OF INFORMATION RELATED TO. Library Philosophy and Practice (e-journal).

Moeller, B. (1996). Learning From Television: A Research Review. Center For Children \& Technology, 50(11).

Mustaqim, K., Adiwijaya, D. R., \& Indrajaya, F. (2013). Penelitian Atas Penelitian Seni dan Desain: Suatu Studi Kerangka FilosofisParadigmatis Bagi Penelitian Seni dan Desain Visual. Humaniora, 4(2), 9951016. https://doi.org/10.21512/humaniora. v4i2.3541

Myutel, M. (2017). Ethnicity and social relations in Indonesian television production houses. Journal of Southeast Asian Studies, 48(2), 219-236. https://doi.org/10.1017/ S0022463417000054

Nandaryani, N. W., \& Santosa, N. A. (2019). Iklan dalam Tayangan Sinetron "Tukang Ojek Pengkolan”. Jurnal Nawala Visual, 1(2), 95-101. https://doi.org/10.35886/ nawalavisual.v1i2.36

Noor-ul-amin, S. (2013). Impact of television watching on academic achievement of adolescents with special reference to their socioeconomic status. Standard Journal of Education and Essay, 1(1), 14-20.

Peirce, L. M., \& Tang, T. (2012). Refashioning Television: Business Opportunities and Challenges of Webisodes. International Journal of Business and Social Science, 3(13), 163-171.

Pietro, G. Di. (2016). The Impact of Television Programmes on Teenage Career
Aspirations: The "MasterChef Effect." IZA Discussion Paper, 9804.

Rahayu, E. K., \& Kurniasari, N. G. A. K. (2019). Peran Produser dalam Produksi Program Percikan Dharma untuk Mempertahankan Rating and Share di RCTI. Prosiding Seminar Nasional Institut Agama Hindu Negeri Tampung Penyang Palangka Raya, 2(September 2019), 12-20.

Siagian, H. F., Mustari, \& Ahmad, F. (2016). The position of da'wah messages and ethics in malaysian and Indonesian television programs. Jurnal Komunikasi: Malaysian Journal of Communication, 32(2), 749-769. https://doi.org/10.17576/ jkmjc-2016-3202-36

Simons, N. (2014). Audience reception of cross- and transmedia TV drama in the age of convergence. International Journal of Communication, 8(1), 2220-2239.

Simons, N. (2015). TV drama as a social experience: An empirical investigation of the social dimensions of watching TV drama in the age of non-linear television. Communications, 40(2), 219-236. https:// doi.org/10.1515/commun-2015-0005

Takeuchi, H., Taki, Y., Hashizume, H., Asano, K., Asano, M., Sassa, Y., Yokota, S., Kotozaki, Y., Nouchi, R., \& Kawashima, R. (2015). The impact of television viewing on brain structures: Cross-sectional and longitudinal analyses. Cerebral Cortex, 25(5), 1188-1197. https://doi.org/10.1093/ cercor/bht315

Yue, Z. (2019). Using television drama as entertainment-education to tackle domestic violence in China. The Journal of development communication, 30(1), 30-44. 